\title{
STUDY ON GAS CHROMATOGRAPHY AND MASS SPECTROSCOPY ANALYSIS, ANTIOXIDANT, AND NUTRITIVE PROPERTIES OF AERVA LANATA (L.) JUSS. COLLECTED FROM SELECTED REGIONS OF SHIMOGA, KARNATAKA, INDIA
}

\author{
VENAKTESH PRASAD YADAV ${ }^{1}$, ASHWATHANARAYANA R ${ }^{1 *}$, PADMASHREE MS ${ }^{2}$
}

${ }^{1}$ Department of PG Studies and Research in Applied Botany, Jnanasahyadri, Kuvempu University, Shankaraghatta, Shimoga - 577 451, Karnataka, India. ${ }^{2}$ Sree Siddaganga College of Arts, Science and Commerce, Tumkur - 572 102, Karnataka, India.

Email: ashwinjamadagni497@gmail.com

Received: 20 June 2018, Revised and Accepted: 11 October 2018

\section{ABSTRACT}

Objective: Aerva lanata (L.) Juss., the plant ethanolic extract was subjected to gas chromatography and mass spectroscopy, antioxidant, and nutritive experiment using standard methods.

Methods: Antioxidant experiment is done using 2, 2-diphenyl-1-picrylhydrazyl, 2, 2-azobis-3-ethylbenthiozoline-6-sulfonic acid, superoxide radical scavenging, hydroxy radical scavenging, and metal-chelating assays. Nutritive value is performed by double acid digestion followed by atomic absorption spectroscopy.

Results: Antioxidant experiment revealed that A. lanata (L.) Juss. the plant ethanolic extract has good medicinal compounds exhibits excellent antioxidant activity in all tested experiments, but comparably less with the standards used. From nutritive value experiment, it is revealed that A. lanata (L.) Juss the plant has high iron content with rich macro- and micro-nutrients.

Conclusion: A. lanata (L.) Juss. could be exploited as a valuable source of antioxidant agent enriching with nutrients.

Keywords: Aerva lanata (L.) Juss., Antioxidant activity, Gas chromatography and mass spectroscopy, Nutritive properties.

(c) 2019 The Authors. Published by Innovare Academic Sciences Pvt Ltd. This is an open access article under the CC BY license (http://creativecommons. org/licenses/by/4. 0/) DOI: http://dx.doi.org/10.22159/ajpcr. 2019.v12i2.27998

\section{INTRODUCTION}

Aerva lanata (L.) Juss. is a weed plant, distributed throughout India, commonly known as weed plant but has many traditional medicinal used.

\section{Botanical description}

Herb, erect, or prostate with a long taproot, branched from near the base; branches many, pubescent or woolly-tomentose, striate.

Leaves alternate, $2-2 \mathrm{~cm} \times 1-1.6 \mathrm{~cm}$ on the main stem, $6-10 \mathrm{~mm} \times 5-6 \mathrm{~mm}$ on the branched, elliptic or obovate, or suborbicular, obtuse or acute, entire, pubescent above, more or less white with cottony hairs beneath; petioles 3-6 mm long, often obscure.

Flowers greenish-white, very small, sessile, often bisexual, in small, dense subsessile axillary heads or spikes 6-13 $\mathrm{mm}$ long often closely crowded and forming globules clusters; bracteoles $1.25 \mathrm{~mm}$, long, membranous, broadly ovate, concave, apiculate, perianth $1.5-1.25 \mathrm{~mm}$ long; sepals oblong, obtuse, sometimes articulate, silky-hairy on the back. Utricle broadly ovoid, acute, stigmas two, seed $0.85 \mathrm{~mm}$ in diameter, smooth and polished, black (Gamble: A. lanata (L.) Juss. Vol - I, 1883).

\section{Common name}

Mountain knotgrass; Hindi-Chaaya; Gorakbudi; Marathi-Kapurmadhuri; Tamil - ciras-pulai; Malayalam - Cherula; Kannada - bili hindi soppu; Telugu - pindidonda; and Sanskrit - asmahabodhaha.

\section{Synonyms}

Achyranthes lanata Roxb.; A. elegans Moq.; and Illecebrum lanatum.

\author{
Taxonomic hierarchy \\ Kingdom: Plantae \\ Subkingdom: Viridiplantae \\ Infrakingdom: Streptophyta \\ Superdivision: Embryophyta \\ Division: Tracheophyta \\ Subdivision: Spermatophytina \\ Class: Magnoliopsida \\ Superorder: Caryophyllanae \\ Order: Caryophyllales \\ Family: Amaranthaceae \\ Genus: Aerva \\ Species: Lanata (L.) Juss.
}

A. lanata (L.) Juss. traditionally used as painkiller in the treatment of headache and for cough, cutaneous infections, in white urine, diarrhea, cholera, dysentery, in kidney stone treatment, anthelmintic, strangury (slow to be and painful discharge of urine), headache, demulcent, anti-inflammatory, diuretic, hepatoprotective, hypoglycemic, antidiabetic, antiparasitic, antimicrobial, antiasthmatic, antifertility, hypolipidemic, antidiuretic, and nephroprotective property also used in the treatment of infections, cough, antidote, emollient, and skin infections [1-4].

Scientifically, A. lanata (L.) Juss. extracts proved for many pharmacological properties such as antinephrolithiasis, antiurolithiatic, diuretic, demulcent, anthelmintic hepatoprotective, anticancer, anti-inflammatory, hypoglycemic, antidiabetic, antiparasitic, hepoprotective, antiurolithiasis, antiasthmatic, antifertility, hypolipidemic, immunomodulatory, antioxidant, cytotoxic, immunomodulatory, and antimicrobial used in anti-HIV treatment and treatment in urinary complaints [5-18] 


\section{METHODS}

\section{Plant collection and authentication}

The plant materials were collected Shimoga District, Karnataka, in January 2018. The plant was identified and authenticated by Dr. Sathish, Kuvempu University, and voucher specimen was conserved under the reference number KU/BD/VPY/001 (Fig. 2).

\section{Plant preparation and extraction}

The plant samples were dried in shade for 20-25 days, mechanically powdered, and subjected to Soxhlet extraction using ethanol. The crude extracts were collected in air-tight plastic containers and stored in cool condition (Fig. 1).

\section{Preliminary phytochemical screening}

Soxhlet extracted solvent crude extracts were screened for the presence of tannins, alkaloids, saponins, glycosides, flavonoids, steroids/sterols, and phenols using standard methods [19].

Gas chromatography and mass spectroscopy (GC-MS) analysis Plant extracts were subjected to GC-MS obtained spectra were analyzed. GC model: Thermo Trace GC Ultra, MS model: Thermo DSQ II, Ionization: Electron impact ionisation (EI), chemical ionisation (CI), mass range: $1-1074 \mathrm{~m} / \mathrm{z}$. The oven temperature was kept at $70-80^{\circ} \mathrm{C}$ and was automated to reach $240-260^{\circ} \mathrm{C}$ at a rate of $8^{\circ} \mathrm{C} / \mathrm{min}$. Mass range was $\mathrm{m} / \mathrm{z} 50-650$. The total running time was completed in 50 min. The chromatogram obtained from GC was then analyzed in MS to get the mass of all fractions. The identification of phytoconstituents

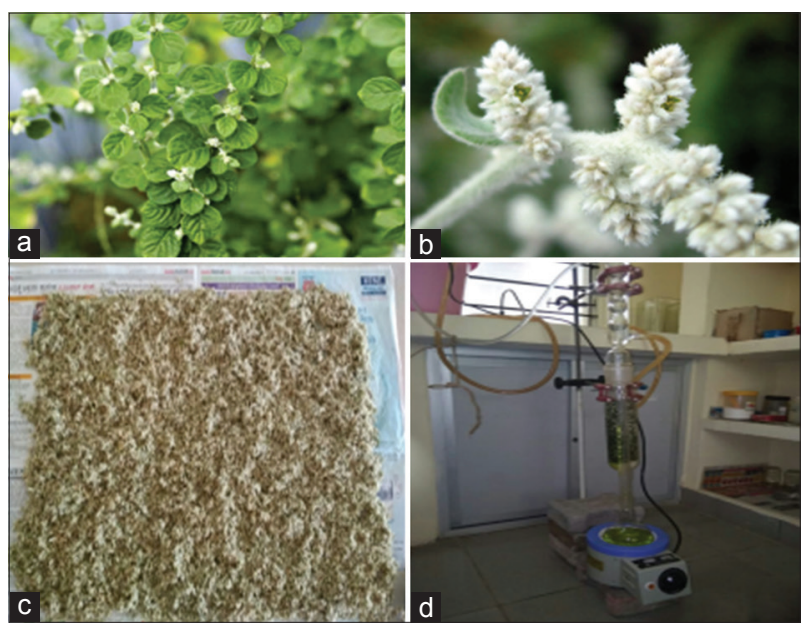

Fig. 1: Aerva lanata (L.) Juss. (a) aerial part, (b) inflorescence, (c) dried grinded sample, (d) Soxhlet extraction

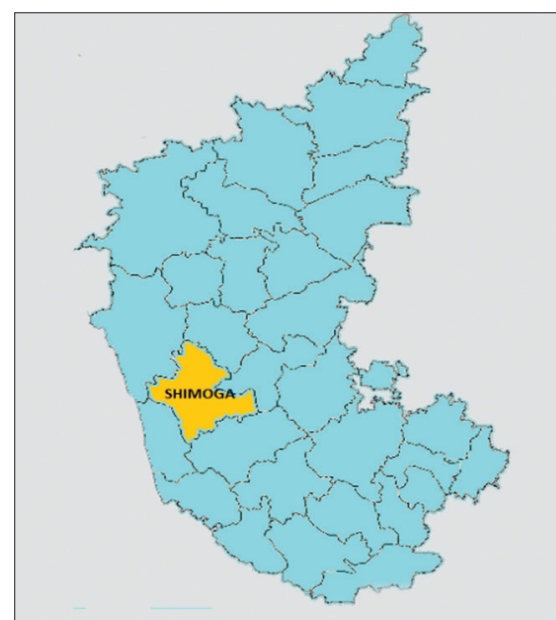

Fig. 2: Location where plants were collected was accomplished by calculating retention time and mass spectra of unknown peaks were measured by comparing with Wiley 9 GC-MS library [20].

\section{In vitro Antioxidant activity}

Scavenging of 2, 2-diphenyl-1-picrylhydrazyl (DPPH) radicals

Stable radical DPPH[21] in methanol was used as a substrate to evaluate antioxidant activity. The method is based on the reduction of DPPH radical in the presence of a hydrogen donating antioxidants, leading to the formation of a non-radical form DPPH-H by the reaction. DPPH in its radical form has an absorption peak at $515 \mathrm{~nm}$ which disappeared on the reduction of antioxidant compounds. Absorbance was measured 20 min after the reaction was started.

Radical scavenging activity was calculated using the following formula:

Percentageinhibition $=\frac{\text { Absorbance of control }- \text { Absorbanceof test }}{\text { Absorbance of control }} \times 100$

Half maximal inhibitory concentration (IC50) value was calculated using the following formula:

Percentageinhibition $=\frac{\text { Absorbance of control }- \text { Absorbanceof test }}{\text { Absorbance of control }} \times 100$

Scavenging of 2, 2-azobis-3-ethylbenthiozoline-6-sulfonic acid (ABTS) radicals

The principle involved in ABTS radical scavenging activity[21] is oxidation of ABTS to its cation radicals by ferryl myoglobin formed in the reaction of $\mathrm{H}_{2} \mathrm{O}_{2}$ and metmyoglobin. Briefly, the stock solutions of $500 \mu \mathrm{M}$ ABTS diammonium salt, $400 \mu \mathrm{M}$ myoglobin (MbIII), 740 $\mu \mathrm{M}$ potassium ferricyanide, and $450 \mu \mathrm{M} \mathrm{H}_{2} \mathrm{O}_{2}$ were prepared in PBS (pH 7.4). Metmyoglobin was prepared by mixing equal volumes of myoglobin and potassium ferricyanide solutions. The reaction mixture $(2 \mathrm{~mL})$ contained ABTS $(150 \mu \mathrm{M})$, MbIII $(2.25 \mu \mathrm{M})$, and varying concentrations of extracts in PBS. The reaction was initiated by adding $75 \mu \mathrm{M} \mathrm{H}_{2} \mathrm{O}_{2}$ and oxidation reaction was monitored at $734 \mathrm{~nm}$.

Elemental composition of $\boldsymbol{A}$. lanata (L.) Juss. aerial parts

The microelements, calcium, magnesium, zinc, copper, manganese, lead, and cadmium were analyzed by atomic absorption spectra GBC 932 AA/AAS. For atomic absorption spectra, plant samples were predigested with nitric acid $\left(\mathrm{HNO}_{3}\right)$ and $\mathrm{HCl}$ in the ratio of $1: 3$ for $1-4 \mathrm{~h}$ depending on the plant sample. Then, the sample is kept over hot water bath $\left(95^{\circ} \mathrm{C}\right)$ for $4-5 \mathrm{~h}$ till the sample completely dissolved $[22,23]$.

\section{RESULTS}

Extracts yield of $\boldsymbol{A}$. lanata (L.) Juss. aerial part ethanolic extract Soxhlet extraction of A. lanata (L.) Juss. aerial part (700 g) with ethanol gives $35.12 \mathrm{~g}$ [Table 1$]$.

Preliminary qualitative phytochemical analysis of $A$. lanata (L.) Juss. aerial part ethanolic extract

The preliminary phytochemical analysis of extracts was given in Table 2. The preliminary phytochemical analysis of ethanolic extract gives positive result for flavonoids, steroids, glycosides, and phenols

Table 1: Extracts yield of Aerva lanata (L.) Juss. aerial part ethanolic extract

\begin{tabular}{lllll}
\hline S No. & Plant part used & $\begin{array}{l}\text { Sample used } \\
\text { in grams }\end{array}$ & $\begin{array}{l}\text { Solvent } \\
\text { used }\end{array}$ & $\begin{array}{l}\text { Extract yield } \\
\text { in grams }\end{array}$ \\
\hline 1 & $\begin{array}{l}\text { Aerva lanata (L.) } \\
\text { Juss. aerial part }\end{array}$ & $700 \mathrm{~g}$ & Ethanol & $35.12 \mathrm{~g}$ \\
& & & & \\
\hline
\end{tabular}


Table 2: Preliminary qualitative phytochemical analysis of Aerva lanata (L.) Juss. aerial part ethanolic extract

\begin{tabular}{llll}
\hline S. No. & $\begin{array}{l}\text { Secondary } \\
\text { metabolites }\end{array}$ & Name of the test & $\begin{array}{l}\text { Ethanolic } \\
\text { extract }\end{array}$ \\
\hline 1 & Alkaloids & $\begin{array}{l}\text { Mayer's test } \\
\text { Wagner's test }\end{array}$ & - \\
& & Foam test & - \\
2 & Saponins & Ferric chloride test & - \\
3 & Tannins & Gelatin test & + \\
& & Shenoda test & + \\
4 & Flavonoids & Zinc HCl reduction test & + \\
& & Alkaline reagent test & + \\
& & Lead acetate test & + \\
5 & Steroids & Ferric chloride test & - \\
6 & Glycosides & Salkowski test & + \\
& & Legal's test & + \\
7 & & Brown water test & + \\
8 & Phenols & Keller-Kiliani test & + \\
9 & Sterols & Tilagic acid test & - \\
\hline
\end{tabular}

Quantitative GC-MS analysis of A. Ianata (L.) Juss. aerial part ethanolic extract

We took only ethanolic extract of A. lanata (L.) Juss. for GC-MS analysis (Table 3 and Figs. 3 and 4).

GC-MS analysis of A. lanata (L.) Juss. aerial part ethanolic extract confirms the presence of 76 compounds, of these 36 compounds were unknown and 40 compounds were known for its medicinal properties, most of them were flavoring agents 13 in numbers, followed by 10 food additive, eight compounds were antioxidant, five compounds have antimicrobial properties, four compounds were anticancer, and rest of them were diuretic, laxative, antineoplastic agent, antiallergic agents, antiseborrheics, insect pheromones, anti-inflammatory, adhesives and sealant chemical, agricultural chemicals (non-pesticidal), finishing agents, lubricants and lubricant additives, surface active agents, anticholinesterase, nasal decongestant, appetite suppressant, anticholesteremic, etc., (Figs 3 and 4; Table 3).

Majorpercentageofcompoundiscis,cis,cis-7,10,13-hexadecatrienal(17.81\%) followed by.gamma.-sitosterol (11.45\%) and pentadecanoic acid (10.09\%) and the least percentage is 3,7,11,15-tetramethyl-2-hexadecen-1-ol (0.08\%).

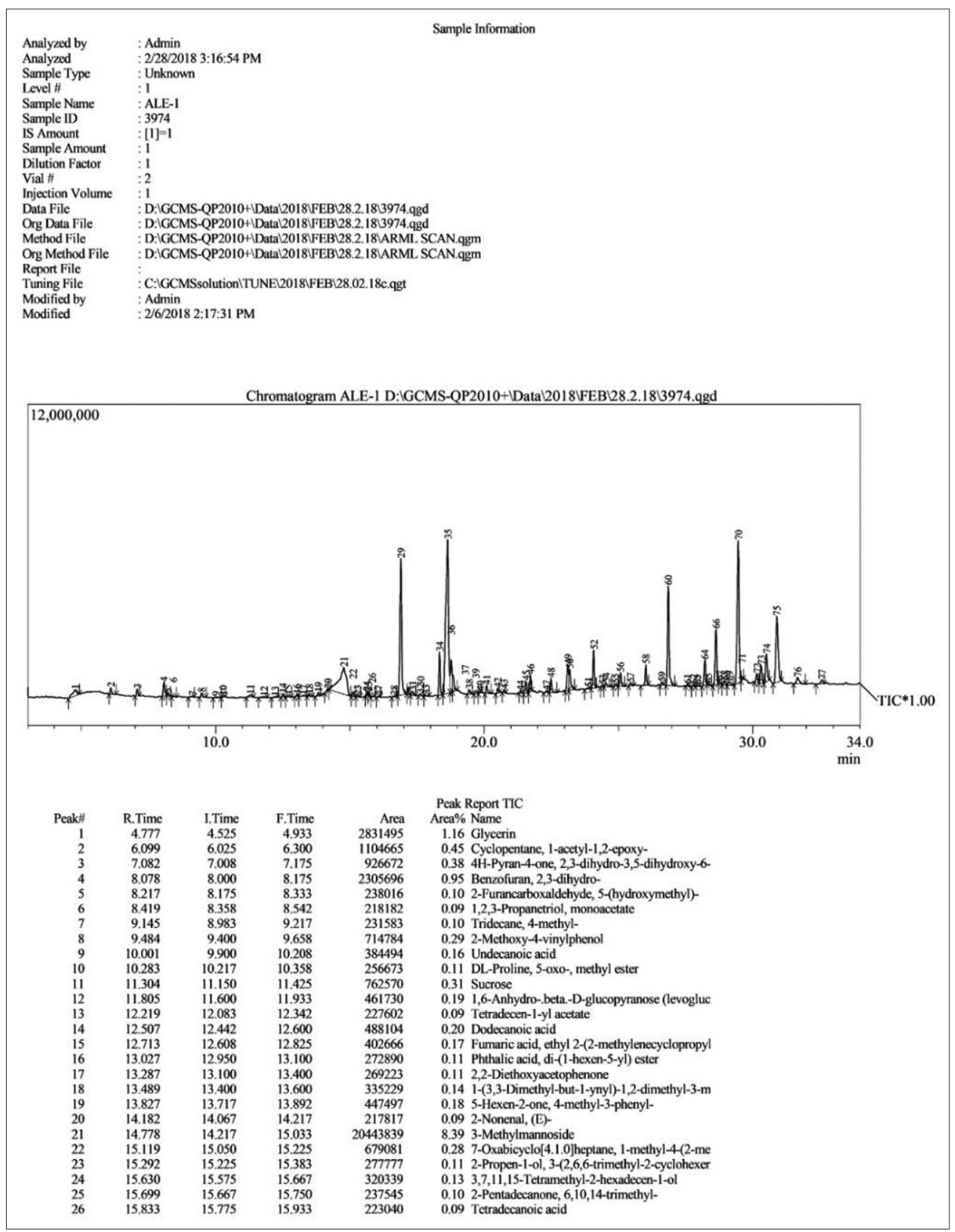

Fig. 3: Gas chromatography and mass spectroscopy analysis of Aerva lanata (L.) Juss. aerial part ethanolic extract 
Table 3: GC-MS analysis of Aerva lanata (L.) Juss. aerial part ethanolic extract

\begin{tabular}{|c|c|c|c|}
\hline S. No. & Phytocompounds in Aerva lanata (L.) Juss. & Percentage & Properties \\
\hline 1 & Glycerin & 1.16 & $\begin{array}{l}\text { Flavoring agent, food additive, diuretic, and laxative } \\
\text { effects [24] }\end{array}$ \\
\hline 2 & Cyclopentane, 1-acetyl-1,2-epoxy- & 0.45 & Unknown \\
\hline 3 & 4H-pyran-4-one, 2,3-dihydro-3,5-dihydroxy-6-methyl- & 0.38 & $\begin{array}{l}\text { Mutagen, antimicrobial, anti-inflammatory, and } \\
\text { antioxidant capacity [25-27] }\end{array}$ \\
\hline 4 & Benzofuran, 2,3-dihydro- & 0.95 & Unknown \\
\hline 5 & 2-furancarboxaldehyde, 5-(hydroxymethyl)- & 0.10 & $\begin{array}{l}\text { Antimicrobial, preservative, flavoring agents, food } \\
\text { additives, component of onion, tomatoes, tobacco oil, } \\
\text { etc., }[28,29]\end{array}$ \\
\hline 6 & 1,2,3-propanetriol, monoacetate & 0.09 & Food additives [30] \\
\hline 7 & Tridecane, 4-methyl- & 0.10 & $\begin{array}{l}\text { Antiandrogenic agent, antineoplastic agent, antiallergic } \\
\text { agents, antiseborrheics [31] }\end{array}$ \\
\hline 8 & 2-methoxy-4-vinylphenol & 0.29 & $\begin{array}{l}\text { Can induce cell cycle arrest, antibacterial, } \\
\text { anti-inflammatory, antioxidant, flavoring agent, also acts } \\
\text { as insect pheromones [32] }\end{array}$ \\
\hline 9 & Undecanoic acid & 0.16 & $\begin{array}{l}\text { Antifungal agent, to treat ringworm and athlete's foot, } \\
\text { food additives, flavoring agent [33] }\end{array}$ \\
\hline 10 & DL-proline, 5-oxo-, methyl ester & 0.11 & Unknown \\
\hline 11 & Sucrose & 0.31 & $\begin{array}{l}\text { Sweetener in foods and soft drinks, in the manufacture } \\
\text { of syrups, in invert sugar, confectionery, preserves and } \\
\text { jams, demulcent, pharmaceutical products, and caramel. } \\
\text { Sucrose is also a chemical intermediate for detergents, } \\
\text { emulsifying agents, and other sucrose derivatives. } \\
\text { Sucrose is widespread in seeds, leaves, fruits, flowers, } \\
\text { and roots of plants, where it functions as an energy } \\
\text { store for metabolism and as a carbon source for } \\
\text { biosynthesis. The annual world production of sucrose } \\
\text { is in excess of } 90 \text { million tons mainly from the juice of } \\
\text { sugar cane ( } 20 \% \text { ) and sugar beet (17\%). In addition to } \\
\text { its use as a sweeter, sucrose is used in food products } \\
\text { as a preservative, antioxidant, moisture control agent, } \\
\text { stabilizer, and thickening agent [34] }\end{array}$ \\
\hline 13 & Tetradecen-1-yl acetate & 0.09 & Unknown \\
\hline 14 & Dodecanoic acid & 0.20 & $\begin{array}{l}\text { Found naturally in various plant and animal fats and } \\
\text { oils, and is a major component of coconut oil and palm } \\
\text { kernel oil. Have antimicrobial properties used in many } \\
\text { soaps and shampoos [36] }\end{array}$ \\
\hline 15 & Fumaric acid, ethyl 2-(2-methylenecyclopropyl) propyl & 0.17 & Unknown \\
\hline 16 & Phthalic acid, di-(1-hexen-5-yl) ester & 0.11 & Unknown \\
\hline 17 & 2,2-diethoxyacetophenone & 0.11 & Unknown \\
\hline 18 & 1-(3,3-dimethyl-but-1-ynyl)-1,2-dimethyl-3-methylene-cyclopr & 0.14 & Unknown \\
\hline 19 & 5-hexen-2-one, 4-methyl-3-phenyl- & 0.18 & Unknown \\
\hline 20 & 2-nonenal, (E)- & 0.09 & $\begin{array}{l}\text { Flavoring agents, food additive, agonists of the AR } \\
\text { signaling pathway [37] }\end{array}$ \\
\hline 21 & 3-methylmannoside & 8.39 & Unknown \\
\hline 22 & 7-oxabicyclo[4.1.0]heptane, 1-methyl-4-(2-methyloxiranyl)- & 0.28 & Moderately toxic [38] \\
\hline 23 & 2-propen-1-ol, 3-(2,6,6-trimethyl-2-cyclohexen & 0.11 & Unknown \\
\hline 24 & 3,7,11,15-tetramethyl-2-hexadecen-1-ol & 0.13 & $\begin{array}{l}\text { A precursor for the manufacture of synthetic forms of } \\
\text { Vitamin E and Vitamin K1, flavoring agents [39] }\end{array}$ \\
\hline 25 & 2-pentadecanone, 6,10,14-trimethyl- & 0.10 & Flavoring agents [40] \\
\hline 26 & 3,7,11,15-tetramethyl-2-hexadecen-1-ol & 0.08 & $\begin{array}{l}\text { Phytol is an acyclic diterpene alcohol and a constituent } \\
\text { of chlorophyll. Phytol is commonly used as a precursor } \\
\text { for the manufacture of synthetic forms of Vitamin E and } \\
\text { Vitamin K1 [39] }\end{array}$ \\
\hline 27 & Methyl-Z, Z-3,13-octadecadieno & 0.10 & Unknown \\
\hline 28 & Pentadecanoic acid & 10.09 & $\begin{array}{l}\text { Adhesives and sealant chemical, agricultural } \\
\text { chemicals (non-pesticidal), finishing agents, lubricants } \\
\text { and lubricant additives, surface active agents [41] }\end{array}$ \\
\hline 29 & Hexadecanoic acid, ethyl ester & 0.38 & Flavoring agents [42] \\
\hline 30 & 1,3-benzenedimethanol, 2-hydroxy-5-methyl- & 0.26 & Unknown \\
\hline
\end{tabular}


Table 1: (Continued)

\begin{tabular}{|c|c|c|}
\hline S. No. & Phytocompounds in Aerva lanata (L.) Juss. & Perc \\
\hline 31 & Oleic acid & 0.14 \\
\hline 32 & Tetradecanoic acid & 0.18 \\
\hline 33 & Phytol & 2.4 \\
\hline 34 & cis, cis, cis-7,10,13-hexadecatrienal & 17 \\
\hline 35 & 9,12-octadecadienoic acid (Z, Z)- & 2.2 \\
\hline 36 & 9,12,15-octadecatrienoic acid, ethyl ester, (Z, Z, Z)- & 0. \\
\hline 37 & Ambrettolide & 0.27 \\
\hline 38 & Benzyl (9Z)-9-octadecenoate & 0.23 \\
\hline 39 & Hexadecanal, 2-methyl- & 0.09 \\
\hline 40 & 2,7-diazido-9H-fluorene & 0.53 \\
\hline 41 & 2H-pyran-2-one, tetrahydro-6-tridecyl- & 0.30 \\
\hline 42 & Sulfurous acid, octadecyl 2-propyl ester & \\
\hline 43 & Benzedrex & \\
\hline
\end{tabular}

Tritetracontane

Hexadecanoic acid, 2-hydroxy-1-(hydroxymethyl)

Sulfurous acid, octadecyl 2-propyl ester

3-methyl-1-oxo-2,3-dihydro-1H-pyrazolo[4,3-c][1,10]

phenanthroline

(R)-(-)-14-methyl-8-hexadecyn-1-ol

Methyl (Z)-5,11,14,17-eicosatetraenoate

Z, Z-8,10-hexadecadien-1-ol

2,6,10,14,18,22-tetracosahexaene, 2,6,10,15,19,23-hexamethyl-, 2 (all-E)- 17-pentatriacontene

1-hexacosanol

0.12

0.37

0.14

2,6,10,15,19,23-hexamethyl-,

(all-E)-

2H-1-benzopyran-6-ol,

3,4-dihydro-2,8-dimethyl-2-(4,8,12-trimethyltridecyl)-,

[2R-[2R*(4R*,8R*)]]-

Tetracosapentaene, 2,6,10,15,19,23-hexamethyl-

Gamma.-tocopherol

17-pentatriacontene

Vitamin E

0.17

6.90

(1)

Percentage

\section{Component in many foods, in the form of its}

triglycerides. It is a component of the normal human diet as a part of animal fats and vegetable oils. Oleic acid as its sodium salt is a major component of soap as an emulsifying agent. It is also used as an emollient. Small amounts of oleic acid are used as an excipient in pharmaceuticals, and it is used as an emulsifying or solubilizing agent in aerosol products [43]

Occurring in most animal and vegetable fats, used to synthesize flavor and as an ingredient in soaps and

cosmetics [44]
A precursor for the manufacture of synthetic forms of Vitamin E and Vitamin K1, flavoring agents[45]

\section{Unknown}

Treatment in the prevention of preeclampsia, flavoring agents, antioxidant, anticholinesterase, and antibacterial activities [46]

\section{Unknown}

Flavoring agents in dairy products [47]

Unknown

Unknown

Unknown

Flavoring agent [48]

Unknown

Is a nasal decongestant, appetite suppressant, and psychostimulant medication. It is an analog of methamphetamine that is used medicinally for relief of congestion due to colds, allergies, and allergic rhinitis and recreationally for its euphoric effects. Used to treat acute nasal congestion related to common cold, allergies, and hay fever [49]

\section{Unknown}

Unknown

Unknown

Unknown

\section{Unknown}

Unknown

Unknown

Squalene is originally obtained from shark liver oil. It is a natural 30-carbon isoprenoid compound and intermediate metabolite in the synthesis of cholesterol. It is not susceptible to lipid peroxidation and provides skin protection. It is ubiquitously distributed in human tissues where it is transported in serum generally in association with very low-density lipoproteins. Squalene is investigated as an adjunctive cancer therapy [50] Unknown It occurs naturally in the epicuticular wax and plant cuticle of many plant species [51] Unknown

Vitamin E component, food additive found in certain nuts and seeds, with potential antioxidant activity [52]

\section{Unknown}

Vitamin E component, food additive found in certain nuts and seeds, with potential antioxidant activity [53] Unknown
Vitamin E, known for its antioxidant activities, is protective against cardiovascular disease and some forms of cancer and has also demonstrated immune-enhancing effects. It may be of limited benefit in some with asthma and rheumatoid arthritis. It may be helpful in some neurological diseases including 
Table 1: (Continued)

\begin{tabular}{|c|c|c|c|}
\hline S. No. & Phytocompounds in Aerva lanata (L.) Juss. & Percentage & Properties \\
\hline & & & $\begin{array}{l}\text { Alzheimer's, some eye disorders including cataracts, and } \\
\text { diabetes, and premenstrual syndrome. It may also help } \\
\text { protect skin from ultraviolet irradiation although claims } \\
\text { that it reverses skin aging, enhances male fertility, and } \\
\text { exercise performance is poorly supported. It may help } \\
\text { relieve some muscle cramps [54] }\end{array}$ \\
\hline 60 & delta. 8-cholesten-3.beta.-ol & 0.12 & Unknown \\
\hline 62 & 22,23-dibromostigmasterol acetate & 0.09 & Unknown \\
\hline 63 & Campesterol & 1.86 & $\begin{array}{l}\text { Naturally occurs in many vegetables, fruits, nuts, and } \\
\text { seeds, anticholesteremic [55] }\end{array}$ \\
\hline 64 & $\begin{array}{l}\text { 9,19-cycloergost-24 (28)-en-3-ol, 4,14-dimethyl-, acetate, } \\
\text { (3.beta.,4.alpha.,5.alpha.)- }\end{array}$ & 0.11 & Unknown \\
\hline 65 & Stigmasterol & 3.91 & $\begin{array}{l}\text { Inhibits certain cancers, food additive, cytotoxicity, } \\
\text { antioxidant, hypoglycemic, and thyroid-inhibiting } \\
\text { properties [56] }\end{array}$ \\
\hline 67 & 7-ergosteno & 0.30 & Unknown \\
\hline 68 & Lanosterol & 0.41 & $\begin{array}{l}\text { Intermediate of cholesterol biosynthesis in animals and } \\
\text { fungus [57] }\end{array}$ \\
\hline 69 & Gamma.-sitosterol & 11.45 & $\begin{array}{l}\text { Hypolipidemic agents isolated from the Indian } \\
\text { marine red alga Gracilaria edulis, the sponge Veronica } \\
\text { aerophoba and the Kenyan Marine Green. Macroalga } \\
\text { Halimeda macroloba [58] }\end{array}$ \\
\hline 70 & Stigmastanol & 0.22 & $\begin{array}{l}\text { Inhibits biosynthesis of cholesterol, anticholesteremic } \\
\text { agents [59] }\end{array}$ \\
\hline 71 & $\begin{array}{l}\text { 4,4,6a, 6b, 8a, 11,11,14b-octamethyl-1,4,4a, 5,6,6a, 6b, 7,8,8a, } \\
9,10,11,12,12 a, 14,14 a\end{array}$ & 0.60 & Unknown \\
\hline 72 & Stigmast-7-en-3-ol, (3.beta.,5.alpha.,24S)- & 1.32 & $\begin{array}{l}\text { Component of ethanolic extract of Chenopodium } \\
\text { formosanum [60] }\end{array}$ \\
\hline 73 & Lupeol & 2.19 & $\begin{array}{l}\text { Naturally found in fruits and vegetables, has } \\
\text { anti-inflammatory agents, analgesic, anticancer activity, } \\
\text { cytotoxicity }[61,62]\end{array}$ \\
\hline 76 & Acetic acid, 3-hydroxy-6-isopropenyl-4,8a-dimethyl-1,2,3,5,6,7,8,8a & 0.35 & Unknown \\
\hline
\end{tabular}

AR: Androgen receptor, GC-MS: Gas chromatography and mass spectroscopy

In vitro antioxidant properties of $A$. Ianata (L.) Juss. aerial part ethanolic extract

A. lanata (L.) Juss. aerial part ethanolic extract subjected to different antioxidant experiments such as DPPH and ABTS. The experiments were triplicated and values were expressed in terms of mean \pm standard error of mean.

DPPH radical scavenging activity of A. lanata (L.) Juss. aerial part ethanolic extract

In DPPH radical scavenging activity, A. lanata (L.) Juss. aerial part ethanolic extract showed dose-dependent radical scavenging activity in all tested concentrations. IC $_{50}$ value of the ethanolic crude extract (129.93 \pm 7.07 ) is not equal to the value of standard ascorbic acid (39.48 \pm 0.02$)$ used, showed moderate antioxidant properties (Table 4 and Fig. 5).

ABTS radical scavenging activity of $\boldsymbol{A}$. lanata (L.) Juss. aerial part ethanolic extract

In ABTS radical scavenging activity of $A$. lanata (L.) Juss. aerial part ethanolic extract showed dose-dependent antioxidant activity in all tested concentrations. $\mathrm{IC}_{50}$ value of the ethanolic crude extract $(84.37 \pm 2.68)$ is not equal to the value of standard butylated hydroxyl anisole $(66.92 \pm 0.36)$ used, showed moderate antioxidant properties (Table 5 and Fig. 6).

\section{Elemental composition of sample}

A. lanata (L.) Juss. aerial part sample subjected for nutrient analysis through atomic absorption spectroscopy. The results were found to be satisfying with sufficient quantity of macronutrients such as nitrogen (3.08 \pm 0.34$)$, phosphorus $(0.15 \pm 0.14)$, potassium ( $2.49 \pm 0.32)$, calcium, and magnesium showed the nil percentage (Table 6 and Fig. 7).
Similarly, micronutrients like iron (404.00 \pm 0.34), manganese $(39.20 \pm 0.52)$, zinc $(27.40 \pm 0.62)$ and copper $(7.85 \pm 0.73)$ were confirmed in appreciable percentage. The values was obtained were expressed in terms of ppm (parts per million) (Table 7 and Fig. 8). In all the nutrient components of $A$. lanata (L.) Juss. aerial part sample, the iron $(404.00 \pm 0.34)$ was found to be highest, which is essential micronutrient mainly help in the treatment of anemic patients having the deficiency of iron in the form of ferrous ion. In developing countries, iron deficiency is the common factor affects the growth of devolving children. Ferrous ions also help in the hemoglobin formation which essential for human beings.

\section{DISCUSSION}

Soxhlet extraction of $\boldsymbol{A}$. lanata (L.) Juss. aerial part

Soxhlet extraction is a common procedure to extract phytoconstituents which is essential to humankind. The aerial part sample (700 g) of A. lanata (L.) Juss. aerial part yields maximum percentage of extract in ethanolic extract ( $35.12 \mathrm{~g}$ ) so it is revealed that the plant aerial part sample is having more alcohol-soluble extractive which is more essential in extraction of good phytoconstituent [Table 1].

Preliminary phytochemical analysis of $A$. lanata (L.) Juss. aerial part ethanolic extract

The preliminary phytochemical analysis of $A$. lanata (L.) Juss. aerial part extracts also revealed the presence of more phytoconstituent in the ethanolic extracts such as alkaloids, saponins, flavonoids, steroids, glycosides, phenols, and sterols. Hence, we took only ethanolic extract for GC-MS analysis for confirmation of different constituents [Table 2]. 


\begin{tabular}{|c|c|c|c|c|c|}
\hline Peak\# & R.Time & I.Time & F.Time & Area & Area\% Name \\
\hline 27 & 16.073 & 15.992 & 16.142 & 203037 & 0.08 3,7,11,15-Tetramethyl-2-hexadecen-1-ol \\
\hline 28 & 16.655 & 16.567 & 16.725 & 233658 & 0.10 Methyl-Z,Z-3,13-octadecadieno \\
\hline 29 & 16.904 & 16.792 & 17.117 & 24589707 & 10.09 Pentadecanoic acid \\
\hline 30 & 17.173 & 17.117 & 17.258 & 914667 & 0.38 Hexadecanoic acid, ethyl ester \\
\hline 31 & 17.329 & 17.267 & 17.442 & 629468 & 0.26 1,3-Benzenedimethanol, 2-hydroxy-5-methyl- \\
\hline 32 & 17.616 & 17.542 & 17.750 & 344740 & 0.14 Oleic Acid \\
\hline 33 & 17.820 & 17.758 & 17.958 & 207252 & 0.09 Tetradecanoic acid \\
\hline 34 & 18.344 & 18.275 & 18.458 & 5844781 & 2.40 Phytol \\
\hline 35 & 18.645 & 18.467 & 18.733 & 43402771 & 17.81 cis,cis,cis-7,10,13-Hexadecatrienal \\
\hline 36 & 18.776 & 18.733 & 18.825 & 5375974 & $2.219,12$-Octadecadienoic acid (Z,Z)- \\
\hline 37 & 18.841 & 18.825 & 19.000 & 2335216 & $0.969,12,15$-Octadecatrienoic acid, ethyl ester, (Z,Z \\
\hline 38 & 19.448 & 19.367 & 19.558 & 660341 & 0.27 Ambrettolide \\
\hline 39 & 19.692 & 19.617 & 19.783 & 559985 & 0.23 Benzyl (9Z)-9-octadecenoate \\
\hline 40 & 19.852 & 19.792 & 19.892 & 231522 & 0.09 Hexadecanal, 2-methyl- \\
\hline 41 & 20.095 & 20.033 & 20.275 & 1281976 & 0.53 2,7-Diazido-9H-fluorene \\
\hline 42 & 20.510 & 20.433 & 20.575 & 719543 & 0.30 2H-Pyran-2-one, tetrahydro-6-tridecyl- \\
\hline 43 & 20.749 & 20.675 & 20.817 & 445224 & 0.18 Sulfurous acid, octadecyl 2-propyl ester \\
\hline 44 & 21.356 & 21.308 & 21.417 & 228735 & 0.09 Benzedrex \\
\hline 45 & 21.551 & 21.475 & 21.650 & 1981692 & 0.81 Tritetracontane \\
\hline 46 & 21.725 & 21.658 & 21.783 & 2171889 & 0.89 Hexadecanoic acid, 2-hydroxy-1-(hydroxymetl \\
\hline 47 & 22.329 & 22.217 & 22.417 & 340876 & 0.14 Sulfurous acid, octadecyl 2-propyl ester \\
\hline 48 & 22.492 & 22.417 & 22.708 & 2371418 & 0.97 3-Methyl-1-oxo-2,3-dihydro-1H-pyrazolo[4,3-1 \\
\hline 49 & 23.123 & 23.025 & 23.158 & 4308631 & 1.77 (R)-(-)-14-Methyl-8-hexadecyn-1-ol \\
\hline 50 & 23.192 & 23.158 & 23.383 & 3683411 & 1.51 Methyl (Z)-5,11,14,17-eicosatetraenoate \\
\hline 51 & 23.890 & 23.742 & 23.950 & 250483 & 0.10 Z,Z-8,10-Hexadecadien-1-ol \\
\hline 52 & 24.081 & 23.992 & 24.175 & 5068931 & $2.082,6,10,14,18,22$-Tetracosahexaene, $2,6,10,15,1^{\prime}$ \\
\hline 53 & 24.403 & 24.325 & 24.458 & 288393 & 0.12 17-Pentatriacontene \\
\hline 54 & 24.542 & 24.458 & 24.742 & 912185 & 0.37 1-Hexacosanol \\
\hline 55 & 24.879 & 24.817 & 24.992 & 335534 & $0.141,6,10,14,18,22$-Tetracosahexaen-3-ol, 2,6,10,1 \\
\hline 56 & 25.078 & 24.992 & 25.250 & 2003159 & 0.82 2H-1-Benzopyran-6-ol, 3,4-dihydro-2,8-dimeth \\
\hline 57 & 25.443 & 25.375 & 25.558 & 484025 & 0.20 Tetracosapentaene, $2,6,10,15,19,23$-hexamethy \\
\hline 58 & 26.024 & 25.842 & 26.133 & 3241768 & 1.33 .gamma-Tocopherol \\
\hline 59 & 26.627 & 26.558 & 26.692 & 405448 & 0.17 17-Pentatriacontene \\
\hline 60 & 26.857 & 26.767 & 27.100 & 16821569 & 6.90 Vitamin $E$ \\
\hline 61 & 27.574 & 27.500 & 27.650 & 298625 & 0.12 delta.8-Cholesten-3.beta.-ol \\
\hline 62 & 27.803 & 27.717 & 27.883 & 294478 & 0.12 Ergost-8-en-3-ol, 14-methyl-, (3.beta.,5.alpha.) \\
\hline 63 & 27.948 & 27.883 & 28.050 & 218684 & 0.09 22,23-Dibromostigmasterol acetate \\
\hline 64 & 28.222 & 28.117 & 28.308 & 4521557 & 1.86 Campesterol \\
\hline 65 & 28.359 & 28.308 & 28.467 & 275208 & 0.11 9,19-Cycloergost-24(28)-en-3-ol, 4,14-dimethy \\
\hline 66 & 28.633 & 28.525 & 28.725 & 9534848 & 3.91 Stigmasterol \\
\hline 67 & 28.773 & 28.725 & 28.842 & 401356 & 0.16 Ergost-25-ene-3,5,6,12-tetrol, (3.beta.,5.alpha., \\
\hline 68 & 28.961 & 28.858 & 29.050 & 739146 & 0.30 7-Ergostenol \\
\hline 69 & 29.126 & 29.050 & 29.308 & 998720 & 0.41 Lanosterol \\
\hline 70 & 29.467 & 29.325 & 29.567 & 27904481 & 11.45 .gamma.-Sitosterol \\
\hline 71 & 29.606 & 29.567 & 29.658 & 541535 & 0.22 Stigmastanol \\
\hline 72 & 30.161 & 30.075 & 30.233 & 1470490 & $0.604,4,6 \mathrm{a}, 6 \mathrm{~b}, 8 \mathrm{a}, 11,11,14 \mathrm{~b}-0$ - tamethyl-1,4,4a,5,6, \\
\hline 73 & 30.316 & 30.233 & 30.417 & 3209354 & 1.32 Stigmast-7-en-3-ol, (3.beta.,5.alpha.,24S)- \\
\hline 74 & 30.520 & 30.425 & 30.625 & 5339031 & 2.19 Lupeol \\
\hline 75 & 30.908 & 30.767 & 31.067 & 17111497 & 7.02 Lup-20(29)-en-3.beta.-ol \\
\hline 76 & 31.678 & 31.533 & 31.967 & 1851175 & 0.76 3.alpha.,7.beta.-Dihydroxy-5.beta.,6.beta.-epox \\
\hline 77 & 32.578 & 32.358 & 32.675 & $\begin{array}{r}860419 \\
243727822\end{array}$ & $\begin{array}{l}0.35 \text { Acetic acid, 3-hydroxy-6-isopropenyl-4,8a-dir } \\
100.00\end{array}$ \\
\hline
\end{tabular}

Fig. 4: Gas chromatography and mass spectroscopy analysis of Aerva lanata (L.) Juss. aerial part ethanolic extract

Table 4: DPPH radical scavenging activity of Aerva lanata (L.) Juss. aerial part ethanolic extract

\begin{tabular}{|c|c|c|c|c|c|c|}
\hline Activity & Extracts & $\begin{array}{l}\text { Concentration } \\
\text { in } \mu \mathrm{g} / \mathrm{mL}\end{array}$ & $\begin{array}{l}\text { Scavenging } \\
\text { activity }\end{array}$ & IC $_{50}$ value & $\begin{array}{l}\text { Standard } \mu \mathrm{g} / \mathrm{mL} \\
\text { (ascorbic acid) }\end{array}$ & $\begin{array}{l}\mathrm{IC}_{50} \text { value of standard } \\
\text { ascorbic acid }\end{array}$ \\
\hline \multirow[t]{8}{*}{ DPPH activity } & Ethanolic & 25 & $17.33 \pm 0.88$ & $129.93 \pm 7.07$ & $76.23 \pm 0.23$ & $39.48 \pm 0.02$ \\
\hline & & 50 & $21.66 \pm 0.66$ & & $82.32 \pm 0.43$ & \\
\hline & & 75 & $31.33 \pm 0.33$ & & $113.11 \pm 0.09$ & \\
\hline & & 100 & $39.66 \pm 0.66$ & & $134.54 \pm 0.91$ & \\
\hline & & 125 & $47.66 \pm 2.18$ & & $156.43 \pm 0.02$ & \\
\hline & & 150 & $57 \pm 1.15$ & & $176.65 \pm 0.34$ & \\
\hline & & 175 & $62.33 \pm 0.88$ & & $189.41 \pm 0.54$ & \\
\hline & & 200 & $69.33 \pm 0.33$ & & $210.87 \pm 0.32$ & \\
\hline
\end{tabular}

\footnotetext{
$\mathrm{IC}_{50}:$ Half maximal inhibitory concentration, DPPH: 2, 2-diphenyl-1-picrylhydrazyl
} 
Table 5: ABTS radical scavenging activity of Aerva lanata (L.) Juss. aerial part ethanolic extract

\begin{tabular}{|c|c|c|c|c|c|c|}
\hline Activity & Extracts & $\begin{array}{l}\text { Concentration } \\
\text { in } \mu \mathrm{g} / \mathrm{mL}\end{array}$ & $\begin{array}{l}\text { scavenging } \\
\text { activity }\end{array}$ & IC $_{50}$ value & $\begin{array}{l}\text { Standard } \mu \mathrm{g} / \mathrm{mL} \\
\text { (butylated hydroxyl anisole) }\end{array}$ & $\begin{array}{l}\text { IC }_{50} \text { value of standard } \\
\text { butylated hydroxyl anisole }\end{array}$ \\
\hline ABTS activity & Ethanolic & $\begin{array}{l}50 \\
100 \\
150 \\
200 \\
250 \\
300 \\
350 \\
400\end{array}$ & $\begin{array}{l}7 \pm 0.57 \\
12.33 \pm 0.66 \\
18.33 \pm 0.88 \\
23 \pm 1.15 \\
33.66 \pm 2.02 \\
39.33 \pm 1.45 \\
46.33 \pm 0.88 \\
55.33 \pm 2.33\end{array}$ & $382.43 \pm 1.34$ & $\begin{array}{l}47.34 \pm 0.32 \\
84.65 \pm 0.05 \\
120.43 \pm 0.36 \\
149.68 \pm 0.1 \\
185.65 \pm 0.3 \\
214.76 \pm 0.62 \\
254.36 \pm 0.06 \\
287.98 \pm 0.6\end{array}$ & $66.92 \pm 0.36$ \\
\hline
\end{tabular}

$\mathrm{IC}_{50}$ : Half maximal inhibitory concentration, ABTS: 2, 2-azobis-3-ethylbenthiozoline-6-sulfonic acid

Table 6: Macronutrient of Aerva lanata (L.) Juss. aerial sample

\begin{tabular}{lllllll}
\hline S. No. & Samples & \multicolumn{2}{l}{ Macronutrients in percentage (mean \pm SD) } & & Ca & Mg \\
\cline { 3 - 7 } & & $\mathbf{N}$ & $\mathbf{P}$ & $\mathbf{K}$ & - & - \\
& & $3.08 \pm 0.34$ & $0.15 \pm 0.14$ & $2.49 \pm 0.32$ & Medium & Medium \\
\hline 1 & Arial part & Medium & Medium & Medium &
\end{tabular}

SD: Standard deviation

Table 7: Micronutrients of Aerva Ianata (L.) Juss. aerial sample

\begin{tabular}{|c|c|c|c|c|c|}
\hline \multirow[t]{2}{*}{ S. No. } & \multirow[t]{2}{*}{ Samples } & \multicolumn{4}{|c|}{ Micronutrients in ppm (mean \pm SD) } \\
\hline & & $\mathrm{Fe}$ & Mn & Zn & $\mathrm{Cu}$ \\
\hline \multirow[t]{2}{*}{1} & Arial part & $404.00 \pm 0.34$ & $39.20 \pm 0.52$ & $27.40 \pm 0.62$ & $7.85 \pm 0.73$ \\
\hline & Occurrence & High & Medium & Medium & Medium \\
\hline
\end{tabular}

SD: Standard deviation

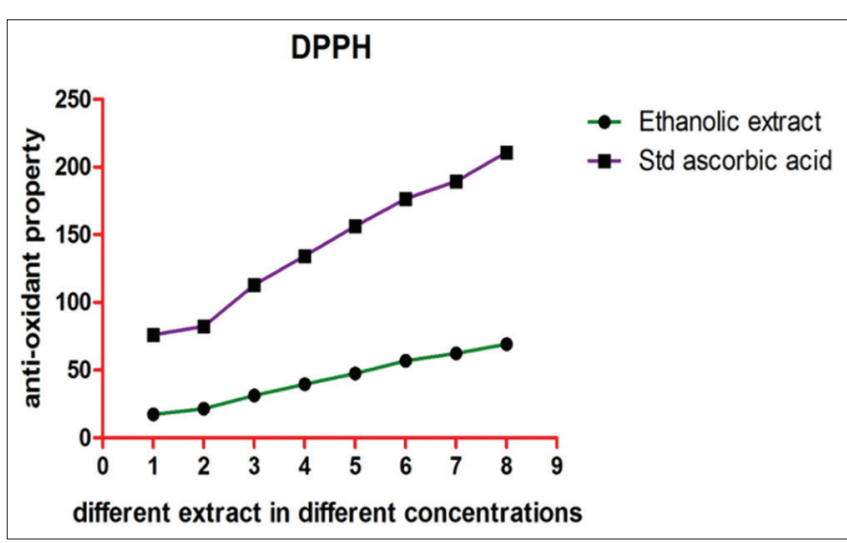

Fig. 5: 2, 2-diphenyl-1-picrylhydrazyl radical scavenging activity of Aerva lanata (L.) Juss. aerial part ethanolic extract

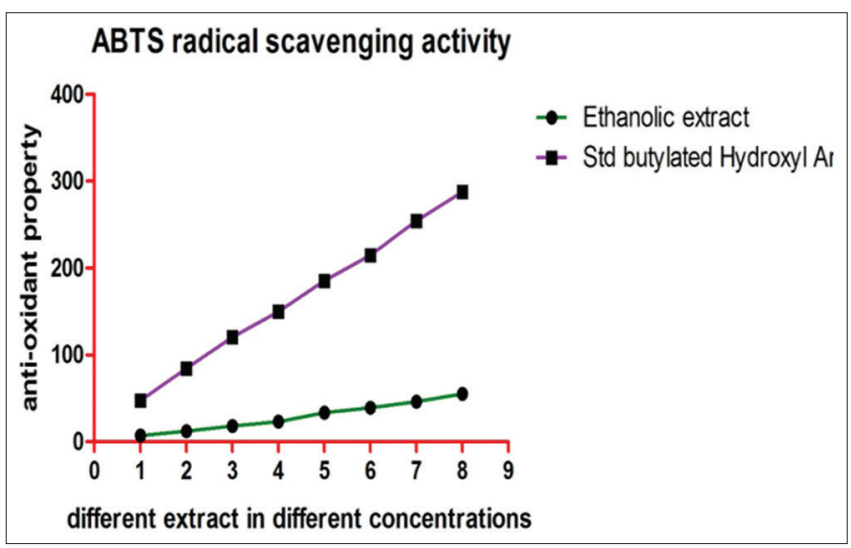

Fig. 6. 2, 2-azobis-3-ethylbenthiozoline-6-sulfonic acid radical scavenging activity of Aerva lanata (L.) Juss. aerial part ethanolic extract

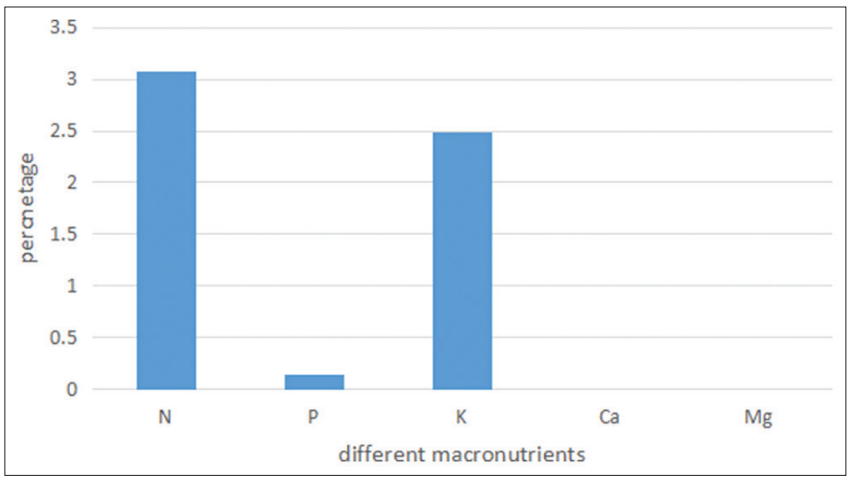

Fig. 7: Macronutrients of Aerva lanata (L.) Juss. aerial sample

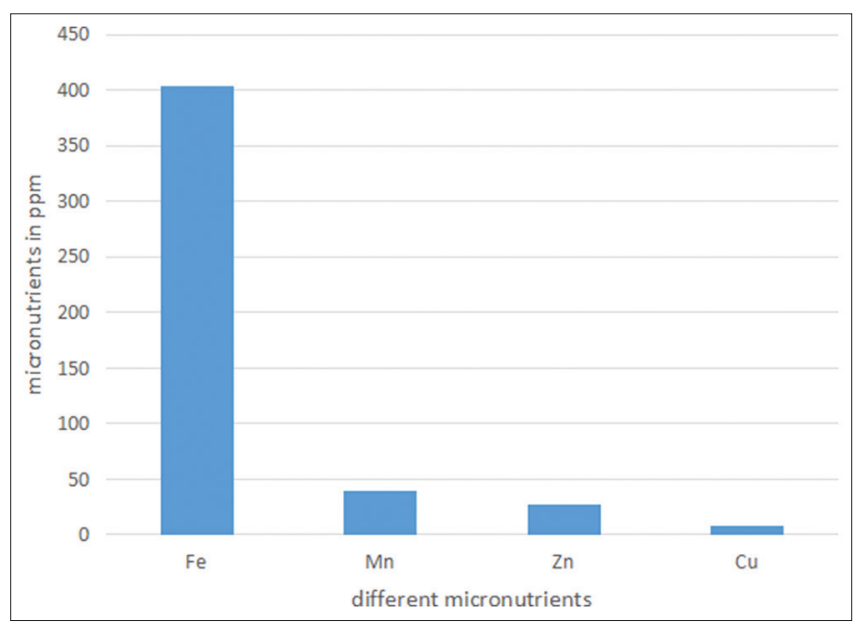

Fig. 8: Micronutrients of Aerva lanata (L.) Juss. aerial sample

GC-MS analysis of $\boldsymbol{A}$. lanata (L.) Juss. aerial part ethanolic extract GC-MS analysis of A. lanata (L.) Juss. aerial part ethanolic extract 
was analyzed in the instrument GC Model: Thermo Trace GC Ultra, MS model: Thermo DSQ II, Ionization: EI, chemical ionization (CI), and mass range: $1-1074 \mathrm{~m} / \mathrm{z}$ and obtained spectra were analyzed, revealed the presence of 76 compounds in that 36 compounds were unknown and 40 compounds were known for its medicinal properties (Figs 3 and 4; Table 3).

Major percentage of compound is cis, cis, cis-7,10,13-Hexadecatrienal (17.81\%) unknown for its pharmacological properties, followed by.gamma.-sitosterol (11.45\%) used as hypolipidemic agents, isolated from the Indian marine red alga Gracilaria edulis, the sponge Veronica aerophoba and the Kenyan marine green Macroalga Halimeda [58], pentadecanoic acid (10.09\%) adhesives and sealant chemical, agricultural chemicals (non-pesticidal), finishing agents, lubricants and lubricant additives, and surface active agents [40], and the least percentage is 3,7,11,15-Tetramethyl-2-hexadecen-1-ol $(0.08 \%)$ used as a precursor for the manufacture of synthetic forms of Vitamin $\mathrm{E}$ and Vitamin K1 [45].

13 compounds were known as flavoring agents used in food industries such as glycerin; 2-furancarboxaldehyde, 5-(hydroxymethyl)-; 2-methoxy-4-vinylphenol; undecanoic acid; 2-nonenal, (E)-; 3,7,11,15-tetramethyl-2-hexadecen-1-ol; 2-pentadecanone, 6,10,14-trimethyl-; hexadecanoic acid, ethyl ester; tetradecanoic acid; phytol; 9,12-octadecadienoic acid (Z, Z)-; ambrettolide; and 2H-pyran-2-one, tetrahydro-6-tridecyl-

10 compounds were known as food additives, used in food and nutrient industries such as glycerin; 2-furancarboxaldehyde, 5-(hydroxymethyl)-; 1,2,3-propanetriol, monoacetate; undecanoic acid; sucrose; oleic acid; 2H-1-benzopyran-6-ol, 3,4-dihyd ro-2,8-dimethyl-2-(4,8,12-trimethyltridecyl)-, [2R-[2R* $\left.\left.\left(4 \mathrm{R}^{*}, 8 \mathrm{R}^{*}\right)\right]\right]-;$.gamma.-tocopherol; stigmasterol; and 2-nonenal, (E)- 4H-pyran-4-one, 2,3-dihydro-3,5-dihydroxy-6-methyl-

Eight compounds were known for its antioxidant properties, namely 2-methoxy-4-vinylphenol; sucrose; 9,12-octadecadienoic acid (Z, Z)-; 2H-1-benzopyran-6-ol, 3,4-dihydro-2,8-dime thyl-2-(4,8,12-trimethyltridecyl)-, [2R-[2R* $\left.\left.\left(4 \mathrm{R}^{*}, 8 \mathrm{R}^{*}\right)\right]\right]-;$.gamma.-tocopherol; Vitamin E; and stigmasterol.

Five compounds were known for its antimicrobial properties, namely 4H-pyran-4-one, 2,3-dihydro-3,5-dihydroxy-6-methyl-; 2-furancarboxaldehyde, 5-(hydroxymethyl)-; dodecanoic acid; undecanoic acid; and lanosterol.

Four compounds were known for its anticancer properties, namely 2-methoxy-4-vinylphenol; stigmasterol; Vitamin E; and lupeol.

Rest of them were diuretic, laxative, antineoplastic agent, antiallergic agents, antiseborrheics, insect pheromones, anti-inflammatory, adhesives and sealant chemical, agricultural chemicals (non-pesticidal), finishing agents, lubricants and lubricant additives, surface active agents, anticholinesterase, nasal decongestant, appetite suppressant, anticholesteremic, etc.

Capesterol is even though present in less quantity has many pharmacological properties such as antibacterial [64,65], antinociceptive [66], and anticarcinogenic [67], and identified in most of the plants such as Syzygium aromaticum [65] and Chrysanthemum coronarium [67].

\section{In vitro antioxidant properties of A. lanata (L.) Juss. aerial part} ethanolic extract

In our study, it is revealed that A. lanata (L.) Juss. aerial part ethanolic extract showed appreciable antioxidant activity in all tested concentrations which is not comparable with the standards used. The antioxidant property of $A$. lanata (L.) Juss. aerial part ethanolic extract is may be due to the presence of eight compounds present in it, such as, 2-methoxy-4-vinylphenol; sucrose; 9,12-octadecadienoic acid (Z, Z)-; 2H-1-benzopyran-6-ol, 3,4-dihyd ro-2,8-dimethyl-2-(4,8,12-trimethyltrid e cyl)-, [2R-[2R* $\left.\left.\left(4 \mathrm{R}^{*}, 8 \mathrm{R}^{*}\right)\right]\right]$-;.gamma.-tocopherol; Vitamin E; and stigmasterol (Tables 4 and 5 and Figs. 5 and 6).

\section{Elemental composition of $A$. lanata (L.) Juss. aerial part Macronutrient}

Potassium (K) was found in normal level in Aerva lananta aerial parts. We need at least 4-5 g of potassium per day to perform normal work, maintain a normal blood pressure, work as an electrolyte in maintaining the body fluid, and maintain normal bone strength.

A. lanata (L.) Juss. aerial parts contain nitrogen $(\mathrm{N})$ percentage in normal level. Nitrogen is a main component of DNA, RNA, and amino acids, an essential nutrient mainly required for protein synthesis and enzymes.

A. lanata (L.) Juss. aerial parts contain phosphorus (P) was found in normal level. In the human body, phosphorus has a vital role in the formation of bone and teeth, helps in the metabolism of carbohydrates and fats, helps in the synthesis of proteins in the human body, and triggers tissue repair mechanism (Table 6 and Fig. 7).

\section{Micronutrient}

In A. lanata (L.) Juss. aerial parts, the copper was found to be normal. Copper is essential for maintenance of brain health, antioxidant defense, the main component of neuron communication, and essential in maintenance of healthy skin.

In A. lanata (L.) Juss. aerial parts, the iron (Fe) was found to be high. The leaves have highest iron content. In human body, iron is an essential component of red blood cells, an important component of some proteins and enzymes, and also acts as enzyme cofactor, normal function of hemoglobin, and myoglobin.

In A. lanata (L.) Juss. aerial parts, manganese (Mn) was found to be in normal condition. In humans, manganese works as mettaloenzymes in the activation of enzyme-substrate reaction, also present in bone, cartilages, and proper functioning of thyroid.

In A. lanata (L.) Juss. aerial parts, zinc (Zn) was found to be in normal condition. In human body, zinc plays a key role in proper function of immune system by activation T-lymphocytes, proper neurophysiological function (Table 7 and Fig. 8).

\section{CONCLUSION}

After the present investigation, it can be concluded that the aerial part ethanolic extract of $A$. lanata (L.) Juss. can act as good antioxidant, as well as having good nutritive value. GC-MS analysis of ethanolic extract revealed the presence of 76 compounds in that 40 compounds were known for its medicinal properties, most of them were antimicrobial agents followed by food additive and flavoring agents, antioxidant, anticancer agents, antihypercholesterolemic compounds, anti-inflammatory agents, analgesic, etc.

The overall study on antioxidant, GC-MS, and elemental nutritive value reports that the plant species contain many active compounds which by their synergistic effect may reduce the inflammation and has an edible value with rich nutrients. Hence, it is finally concluded that the aerial part ethanolic extract of $A$. lanata (L.) Juss. can be explored for potential antioxidant and nutritive compounds.

\section{ACKNOWLEDGMENT}

The authors would like to thank the Department of Applied Botany, Kuvempu University, Karnataka, for providing facilities to conduct our experimental work 


\section{AUTHORS' CONTRIBUTION}

Mr. Venkatesh Prasad Yadav and Ashwathanarayana R have collected the data, conducted the experiment and Mrs. Padmashree MS drafted the article.

\section{CONFLICTS OF INTEREST}

The authors declared that there are conflicts of interest.

\section{REFERENCES}

1. Goyal M, Pareek A, Nagori BP, Sasmal D. Aerva lanata: A review on phytochemistry and pharmacological aspects. Pharm Rev 2011;5:195-8.

2. Payal C, Gurlaganjeet K, Davinder K, Gagan S, Amit C, Dhawan RK. A review on phytochemistry and biological activity of Aerva lanata $\mathrm{L}$. Med Pharm Plants 2015;4:2-4.

3. Malode UG. Pharmacognostic studies on ethnomedicinal plant Aerva lanata (L.) juss. Int J Pharm Biosci 2017;8:229-34.

4. Athira P, Sreesha N. Pharmacognostic review of medicinal plant Aerva lanata (L.). J Pharm Sci Res 2017;9:1420-3.

5. Nevin KG, Vijayammal PL. Pharmacological and immunomodulatory effects of Aerva lanata. in daltons lymphomaascites-bearing mice. Pharm Biol 2008;43:640-6.

6. Rajesh R, Chitra K, Padmaa M, Paarakh A, Chidambaranathan N. Anticancer activity of aerial parts of Aerva lanata (L.) Juss. Ex Schultagainst dalton's ascitic lymphoma. Eur J Integr Med 2011;3:245-50.

7. Rajesh R, Chitra K, Padmaa M, Paarakh. In vitro anthelmintic activity of aerial parts of Aerva lanata Linn Juss. Int J Pharm Sci Drug Res 2010;2:269-71.

8. Arthi I, Subburaju T, Laxminarayanan B, Rajkumar LA. In vitro evaluation of antioxidant activity of aqueous extract of Aerva lanata (L.). J Pharm Res 2012;5:66-8.

9. Kumar G, Karthik L, Rao VB. Phytochemical composition of in vitro antioxidant activity of aqueous extract of Aerva lanata (L.) juss. Ex schult. stem (Amaranthaceae). Asian Pac J Trop Med 2013;6:180-7.

10. Ganesan P, Ramachandran T, Karthik T, Anand VS, Gowthaman T. Process optimization of Aerva lanata extract treated textile material for microbial resistance in healthcare textiles. Fibers Polym 2013;14:1663-73.

11. Thangavel A, Balakrishnan S, Armugam A, Duraisamy S, Muthusamy S. Phytochemical screaning, GCMS analysis of phytochemical constituents and antibacterial activity of Aerva lanata (L.) leaves. Afr J Pharm Pharm 2014;8:126-35.

12. Bitasta M, Madan S. Aerva lanata (L.): A blessing of mother nature. J Pharm Phytochem 2016;5:92-101.

13. Kayalvizhi D, Shivakumar V, Jayanthi M. Phytochemical screening and antinephrolithiasis activity of ethanol extract of Aerva lanata on ethylene glycol induced renal stone in rats. J Pharm Technol 2015;8:1481-6.

14. Krishnamurthi R. Phytochemical analysis and antioxidant property of Aerva lanata (L.). Int J Pharm 2015;2:426-9.

15. Manohari R, Prasanna G. In vitro antioxidants and antimicrobial activities of Aerva lanata L. Int J Pharm Pharm Res 2016;6:191-201.

16. Vidhya R, Udaykumar R. Phytochemical screening and evaluation of in vitro haemolytic, thrombolytic and anti inflamatory activities of Aerva lanata (L.). Indo Am J Pharm Res 2016;6:5965-73.

17. Abdulmuthalib U, Manjur Shah M. Phytochemical screening on the antioxidant properties of Aerva lanata flower extracts and their in vitro anti proliferative effects on human liver cancer cell line running head- phytochemical screening of flower extracts of Aerva lanata. J Biol Nat 2017;7:81-90

18. Gujjeti RP, Mamidala E. Anti-HIV Activity of phytosterol isolated from Aerva lanata Roots. Rev J Field Pharm 2017;9:112-6.

19. Harborne JB. Phytochemical Methods: A Guide to Modern Techniques of Plant Analysis. $3^{\text {rd }}$ ed. New York: Chapman and Hall Co.; 1998. p. 1-302.

20. Thangavel A, Balakrishnan S, Duraisamy SV. Phytochemical screening, gas chromatography-mass spectrometry (GC-MS) analysis of phytochemical constituents and antibacterial activity of Coriandrum sativum (1) seeds. Int J Pharm Pharm Sci 2015;7:153-9.

21. Alzoreky N, Nakahara N. Antioxidant activity of edible Yemeni plants evaluated by ferryl myoglobin/ABTS assay. Food Sci Techno Res 2001;7:141-4

22. Ang H, Lee K. Analysis of mercury in Malaysian herbal preparations; a peer-review. Biomed Sci 2005;4:31-6.
23. Uddin AB, Khalid RS, Alaama M, Abdualkader AM, Kasmuri A, Abbas SA. Comparitive study of three digestion methods for elemental analysis in traditional medicine products using atomic absorption spectrometry. J Anal Sci Technol 2016;7:2-7.

24. PubChem-Glycerin/ $\mathrm{C}_{3} \mathrm{H}_{8} \mathrm{O}_{3}$. Available from: https://www.pubchem. ncbi.nlm.nih.gov/compound/glycerol.

25. Hiramoto K, Nasuhara A, Michikoshi K, Kato T, Kikugawa K. DNA strand-breaking activity and mutagenicity of 2,3-dihydro-3,5-dihydroxy-6-methyl-4H-pyran-4-one (DDMP), a Maillard reaction product of glucose and glycine. Mutat Res/Genet Toxicol Environ Mutagen 1997;395:47-56.

26. Kumar PP, Kumaravel S, Lalitha C. Screening of antioxidant activity, total phenolics and GC-MS study of Vitex negundo. Afr J Biochem Res 2010;4:191-5.

27. Yu X, Zhao M, Liu F, Zeng $\mathrm{S}$, Hu J. Identification of 2,3-dihydro-3,5-dihydroxy-6-methyl-4H-pyran-4-one as a strong antioxidant in glucose-histidine Maillard reaction products. Food Res Int 2013;51:397-403.

28. Gopalakrishnan S, Vadivel E. GC-MS analysis of some bioactive constituents of Mussaenda frondosa LINN. Int J Pharm Bio Sci 2011;2:313-20

29. PubChem- 5-(Hydroxymethyl)-2-furaldehyde $/ \mathrm{C}_{6} \mathrm{H}_{6} \mathrm{O}_{3}$. Available from: https://www.pubchem.ncbi.nlm.nih.gov/compound/5-hydroxymethylfurfural.

30. PubChem- 1,2,3-Propanetriol, Monoacetate $/ \mathrm{C}_{5} \mathrm{H}_{10} \mathrm{O}_{4}$. Available from: https://www.pubchem.ncbi.nlm.nih.gov/compound/Acetin.

31. PubChem- 4-Methyltridecane $/ \mathrm{C}_{14} \mathrm{H}_{30}$. Available from: https://www. pubchem.ncbi.nlm.nih.gov/compound/4-Methyltridecane.

32. PubChem- 2-Methoxy-4-vinylphenol $/ \mathrm{C}_{9} \mathrm{H}_{10} \mathrm{O}_{2}$. Available from: https:// www.pubchem.ncbi.nlm.nih.gov/compound/2-Methoxy-4-vinylphenol.

33. PubChem- Undecanoic acid $/ \mathrm{C}_{11} \mathrm{H}_{22} \mathrm{O}_{2}$. Available from: https://www. pubchem.ncbi.nlm.nih.gov/compound/undecanoic acid.

34. PubChem- Sucrose $/ \mathrm{C}_{12} \mathrm{H}_{22} \mathrm{O}_{11}$. Available from: https://www.pubchem. ncbi.nlm.nih.gov/compound/sucrose.

35. PubChem- Levoglucosan $/ \mathrm{C}_{6} \mathrm{H}_{10} \mathrm{O}_{5}$. Available from: https://www. pubchem.ncbi.nlm.nih.gov/compound/Leucoglucosan.

36. PubChem- Lauric acid/ $\mathrm{C}_{12} \mathrm{H}_{24} \mathrm{O}_{2}$. Available from: https://www. pubchem.ncbi.nlm.nih.gov/compound/lauric_acid.

37. PubChem- 2-Nonenal/ $\mathrm{C}_{9} \mathrm{H}_{16} \mathrm{O}$. Available from: https://www.pubchem. ncbi.nlm.nih.gov/compound/trans-2-Nonenal

38. PubChem- Limonene dioxide/ $\mathrm{C}_{10} \mathrm{H}_{16} \mathrm{O}_{2}$. Available from: https://www. pubchem.ncbi.nlm.nih.gov/compound/Limonene dioxide.

39. PubChem-Phytol/ $\mathrm{C}_{20} \mathrm{H}_{40} \mathrm{O}$. Available from: https://www.pubchem.ncbi. nlm.nih.gov/compound/3_7_11_15-tetramethyl-2-hexadecen-1-ol.

40. PubChem-6,10,14-Trimethylpentadecan-2-one/ $\mathrm{C}_{18} \mathrm{H}_{36} \mathrm{O}$ Available from: https://www.pubchem.ncbi.nlm.nih.gov/ compound/6_10_14-Trimethylpentadecan-2-one.

41. PubChem-Pentadecanoic acid/ $\mathrm{C}_{15} \mathrm{H}_{30} \mathrm{O}_{2}$. Available from: https://www. pubchem.ncbi.nlm.nih.gov/compound/pentadecanoic_acid.

42. PubChem-Ethyl palmitate/ $\mathrm{C}_{18} \mathrm{H}_{36} \mathrm{O}_{2}$. Available from: https://www. pubchem.ncbi.nlm.nih.gov/compound/ethyl palmitate.

43. PubChem-Oleic acid/ $/ \mathrm{C}_{18} \mathrm{H}_{34} \mathrm{O}_{2}$. Available from: https://www.pubchem. ncbi.nlm.nih.gov/compound/oleic acid.

44. PubChem-Myristic acid $/ \mathrm{C}_{14} \mathrm{H}_{28} \mathrm{O}_{2}$. Available from: https://www. pubchem.ncbi.nlm.nih.gov/compound/Tetradecanoic_acid.

45. PubChem-Phytol/ $\mathrm{C}_{20} \mathrm{H}_{40} \mathrm{O}$. Available from: https://www.pubchem.ncbi. nlm.nih.gov/compound/Phytol.

46. PubChem-Octadeca-9,12-dienoic acid/ $\mathrm{C}_{18} \mathrm{H}_{32} \mathrm{O}_{2}$. Available from: https://www.pubchem.ncbi.nlm.nih.gov/compound/3931.

47. PubChem-Isoambrettolide/ $\mathrm{C}_{16} \mathrm{H}_{28} \mathrm{O}_{2}$. Available from: https://www. pubchem.ncbi.nlm.nih.gov/compound/Isoambrettolide.

48. PubChem -delta-Octadecalactone $/ \mathrm{C}_{18} \mathrm{H}_{34} \mathrm{O}_{2}$. Available from: https:// www.pubchem.ncbi.nlm.nih.gov/compound/518573.

49. Wikipedia-Propylhexedrine. Available from: https://www.en.wikipedia. org/wiki/Propylhexedrine.

50. PubChem-Squalene $/ \mathrm{C}_{30} \mathrm{H}_{50}$. Available from: https://www.pubchem. ncbi.nlm.nih.gov/compound/squalene.

51. Wikipedia-1-Hexacosanol. Available from: https://www.en.wikipedia. org/wiki/1-Hexacosanol.

52. PubChem-delta-Tocopherol/ $\mathrm{C}_{27} \mathrm{H}_{46} \mathrm{O}_{2}$. Available from: https://www. pubchem.ncbi.nlm.nih.gov/compound/586537.

53. PubChem-gamma-Tocopherol/ $\mathrm{C}_{28} \mathrm{H}_{48} \mathrm{O}_{2}$. Available from: https://www. pubchem.ncbi.nlm.nih.gov/compound/gamma-Tocopherol.

54. PubChem-Vitamin $E / \mathrm{C}_{29} \mathrm{H}_{50} \mathrm{O}_{2}$. Available from: https://www.pubchem. ncbi.nlm.nih.gov/compound/alpha-Tocopherol.

55. PubChem-Campesterol/ $\mathrm{C}_{28} \mathrm{H}_{48} \mathrm{O}$. Available from: https://www. pubchem.ncbi.nlm.nih.gov/compound/campesterol.

56. PubChem-Stigmasterol $/ \mathrm{C}_{29} \mathrm{H}_{48} \mathrm{O}$. Available from: https://www. 
pubchem.ncbi.nlm.nih.gov/compound/Stigmasterin.

57. PubChem-Lanosterol/ $\mathrm{C}_{30} \mathrm{H}_{50} \mathrm{O}$. Available from: https://www.pubchem. ncbi.nlm.nih.gov/compound/lanosterol

58. PubChem-gamma-Sitosterol/ $\mathrm{C}_{29} \mathrm{H}_{50} \mathrm{O}$. Available from: https://www. pubchem.ncbi.nlm.nih.gov/compound/Clionasterol.

59. PubChem-Stigmastanol/ $\mathrm{C}_{29} \mathrm{H}_{52} \mathrm{O}$. Available from: https://www. pubchem.ncbi.nlm.nih.gov/compound/Fucostanol.

60. PubChem-Stigmast-7-en-3-ol, (3beta, 5alpha)-/ $\mathrm{C}_{29} \mathrm{H}_{50} \mathrm{O}-$ https://www. pubchem.ncbi.nlm.nih.gov/compound/6432515.

61. PubChem- Lupeol/ $\mathrm{C}_{30} \mathrm{H}_{50} \mathrm{O}$. Available from: https://www.pubchem. ncbi.nlm.nih.gov/compound/Lupeol.

62. Saleem M. Lupeol. A Novel anti-inflammatory and anti-cancer dietary triterpene. Cancer Lett 2009;5:109-15.

63. PubChem- 3alpha, 7beta-Dihydroxy-5beta, 6beta-epoxycholestane/ $\mathrm{C}_{27} \mathrm{H}_{46} \mathrm{O}_{3}$-. Available from: https://www.pubchem.ncbi.nlm.nih.gov/ compound $/ 2221626$

64. Cai L, Wu CD. Compounds from Syzygium aromaticum possessing growth inhibitory activity against oral pathogens. J Nat Prod 1996;59:987-90

65. Mittal M, Gupta N, Parashar P, Mehra V, Khatri M. Phytochemical evaluation and pharmacological activity of Syzygium aromaticum: A comprehensive review. Int J Pharm Pharm Sci 2014;6:67-72.

66. Kamurthy H, Ch S, Rao SN, Sudhakar M. Antinocieptive activity of stigmasterol-3-glyceryl-2-linoleiate, campesterol and daucosterol isolated from Aerva lanata Linn. Aerial parts. Asian J Pharm Clin Res 2013;6:149-50.

67. Choi J, Lee E, Lee H, Kim K, Ahn K, Shim B, et al. Identification of campesterol from Chrysanthemum coronarium L. And its antiangiogenic activities. J Phytother Res 2007;21:954-9. 